\title{
PENINGKATAN KUALITAS IMPLEMENTASI KURIKULUM PAK SEBAGAI UPAYA PENGEMBANGAN MORALITAS BAGI PELAJAR
}

\author{
Oleh : Pdt. Ribka Baransano, S.PAK., M.Pd.K \\ Ketua Prodi Pendidikan Agama Kristen (S1)
}

\begin{abstract}
ABSTRAK
Pada zaman modernisasi ini maka terlihat banyak sekali perubahan yang terjadi dalam kehidupan manusia, oleh karena itu pendidikan agama sangatlah penting untuk diajarkan di sekolah dengan tujuan untuk menolong moralitas para siswa yang semakin lama semakin jauh dari kebenaran Allah. Untuk itu pendidikan harus diletakkan pada empat pilar yaitu belajar mengetahui (Learning to know), belajar melakukan (Learning to do), belajar hidup dalam kebersamaan (Learning to live together), dan belajar menjadi diri sendiri (Learning to be), dan hal ini harus dikembangkan dalam pembangunan manusia pada masa kini dan masa yang akan dating. Hal yang sangat penting untuk diperhatikan dalam pengembangan kompetensi adalah Kurikulum sebagai alat pendidikan. Dalam hal ini kurikulum diharapkan mampu memecahkan berbagai persoalan bangsa, khususnya dalam bidang pendidikan dengan mempersiapkan peserta didik, melalui perencanaan, pelaksanaan dan evaluasi erhadap sistem pendidikan secara efektif, efisien, dan berhasil guna.
\end{abstract}

\section{Kata Kunci : Kualitas, Kurikulum PAK, Pengembangan, Moralitas, Pelajar}




\section{A. PENDAHULUAN}

Dalam memasuki era globalisasi dan pasar bebas, maka manusia diperhadapkan pada perubahan-perubahan yang tidak menentu. Menghadapi perubahan-perubahan atau perkembangan hidup modern dengan eksis negatifnya, maka pendidikan atau proses belajar mengajar di sekolah terutama dalam bidang agama, dipandang sebagai salah satu cara mempertahankan diri dan eksistensi manusia yang tepat.

Untuk itu pendidikan harus diletakkan pada empat pilar yaitu belajar mengetahui (Learning to know), belajar melakukan (Learning to do), belajar hidup dalam kebersamaan (Learning to live together), dan belajar menjadi diri sendiri (Learning to be), dan hal ini harus dikembangkan dalam pembangunan manusia pada masa kini dan masa yang akan datang. ${ }^{1}$

Hal yang sangat penting untuk diperhatikan dalam pengembangan kompetensi adalah Kurikulum sebagai alat pendidikan. Dalam hal ini kurikulum diharapkan mampu memecahkan berbagai persoalan bangsa, khususnya dalam bidang pendidikan dengan mempersiapkan peserta didik, melalui perencanaan, pelaksanaan dan evaluasi erhadap sistem pendidikan secara efektif, efisien, dan berhasil guna. ${ }^{2}$ Berkaitan dengan kurikulum, maka sangat penting dan perlu untuk kurikulum diterapkan dan dikembangkan bagi pendidikan sesuai dengan perkembangan zaman, untuk dapat membekali peserta didik dengan berbagai kemampuan sesuai dengan tuntutan zaman guna menjawab tantangan arus globalisasi bagi pembangunan masyarakat. ${ }^{3}$

Menurut Sudjatmiko dan Lili Nurlaili, bahwa perkembangan dan perubahan yang terjadi dalam kehidupan bermasyarakat, berbangsa dan bernegara di Indonesia tidak terlepas dari pengaruh perubahan global, perkembangan ilmu pengetahuan dan teknologi, seni dan budaya. Perkembangan dan perubahan secara terus menerus ini menuntut perlunya perbaikan sistim Pendidikan Nasional termasuk penyempurnaan kurikulum untuk mewujudkan masyarakat yang

\footnotetext{
${ }^{1}$ E. Mulyasa, Kurikulum Berbasis Kompetensi (Bandung: PT Remaja Rosdakarya, 2004), hlm. v-vi.

${ }^{2}$ Ibid.

${ }^{3}$ Ibid., hlm. vi.
} 
mampu bersaing dan menyesuaikan diri dengan perubahan zaman tersebut. ${ }^{4}$

Dalam dunia pendidikan kurikulum sangat penting bagi guru dalam melaksanakan tugas mendidik dan mengajar untuk mencapai tujuan pendidikan, untuk itu guru perlu meningkatkan kualitas implementasi kurikulum baik kurikulum umum maupun kurikulum PAK.

Kohlberg mengatakan bahwa dalam beberapa tahun terakhir ini kegiatan moralisasi guru disebut "Kurikulum Tersamar" (hidden curriculum). Dan sejumlah penulis lain juga menyatakan bahwa terbentuknya secara tak sadar seluruh kegiatan guru oleh pelbagai tuntutan pengelolaan kelas dan sekolah sebagai sistem sosial, justru melaksanakan tugas-tugas tersamar dalam upaya menyesuaikan anak terhadap masyarakatnya. ${ }^{5}$

Kohlberg juga menyatakan bahwa dalam kurikulum tersamar bahwa, kebanyakan guru tidak menyadari sepenuhnya bahwa mereka seharusnya berurusan dengan persoalan-peroalan pendidikan moral, bahwa mereka sendiri tidak memiliki pandangan yang jelas mengenai pendidikan moral, dan bahwa mereka tidak pernah memperoleh suatu latihan atau pendidikan dalam pendidikan moral tersebut. ${ }^{6}$

Oleh karena itu maka guru perlu meningkatkan kualitas pelayanannya dalam menyiapkan silabus dan rencana pelaksanaan pembelajaran untuk mengajar, sehingga dalam Proses Belajar Mengajar dan interaksi antara guru dan siswa dapat merubah tingkah laku dan kebiasaan-kebiasaan yang buruk dari siswa dan dapat mengembangkan moralitas dari setiap siswa ke arah yang lebih baik.

Penulis merasa bahwa ini adalah hal yang sangat penting untuk tetap diperhatikan oleh pemerintah, bangsa dan negara dan tetap diatur dalam peraturan pemerintah tentang kurikulum Pendidikan Nasional, untuk meningkatkan mutu pendidikan bangsa, pada masa kini dan masa yang akan datang, agar pendidikan di Indonesia pada umumnya dan Papua pada khususnya tidak ketinggalan teapi mutunya semakin meningkat dalam memasuki era globalisasi dan pasar bebas, sehingga

${ }^{4}$ Sudjatmiko dan Lili Nurlaili, Kurikulum Berbasis Kompetensi dalam menunjang kecakapan hidup siswa, Departemen Pendidikan Nasional Direktorat Jenderal Pendidikan Dasar dan Menengah Direktorat Tenaga Kependidikan, 2004.

${ }^{5}$ Lawrence Kohlberg, Tahap-tahap Perkembangan Moral (Yogyakarta: Penerbit Kanisius, 1995), hlm. 118.

${ }^{6}$ Ibid. 
kita bangsa Indonesia juga bisa bersaing dengan bangsa-bangsa lain di dunia.

\section{B. PENINGKATAN KUALITAS IMPLEMENTASI KURIKULUM PAK}

\section{Pengertian Implementasi}

Kata "Implementasi" dalam Kamus Besar Bahasa Indonesia adalah Pelaksanaan atau Penerapan. ${ }^{7}$ Implementasi evaluasi pendidikan yang ditetapkan pemerintah, yaitu pada ujian nasional 2006 secara umum dinyatakan berlangsung dengan sukses. Implementasinya seringkali menimbulkan jarak, begitu juga dengan Implementasi kurikulum Tingkat satuan pendidikan, dalam implementasinya (yang saat itu masih dalam masa transisi), namun dibeberapa daerah sudah mulai menunjukkan indikator adanya kesulitan pelaksanaannya. ${ }^{8}$

Kurikulum tidak akan tercapai jika hanya dibiarkan setelah dikembangkan. Kurikulum yang telah didesain optimal harus diimplementasikan dan mempunyai hasil bagi pembelajaran. Banyak kurikulum yang telah didesain dan dikembangkan tidak diimplementasikan karena ketiadaan suatu rencana perubahan dalam keseluruhan suatu sistem persekolahan.

Kurikulum baru yang gagal boleh jadi karena alasan belum mempertimbangkan pengembangan kurikulum secara kritis. Seringkali, individu dalam sekolah percaya bahwa usaha kurikulum adalah untuk melengkapi rencana baru yang dikembangkan atau material baru yang dibeli. Perhatian lebih banyak diberikan pada permasalahan manajemen dan organisasi dibanding pada perubahan kurikulum. ${ }^{9}$

Implementasi yang sukses adalah suatu proses yang mempunyai beberapa hal baru. Implementasi tergantung pada pendekatan umum pengembangan kurikulum dan kurikulum itu sendiri. Kebanyakan orang percaya bahwa implementasi yang sukses, berdasarkan pada penggambaran langkah-langkah yang tepat yang terutama menyangkut

\footnotetext{
${ }^{7}$ Tim Penyusun, Kamus Besar Bahasa Indonesia, Edisi keempat (Jakarta: PT Gramedia Pustaka Utamaa, 2011), hlm. 529.

${ }^{8} \mathrm{http}: / / w w w . a g a t o s s i . c o m / 2012 / 09 /$ evaluai-kualutas-kurikulum-pendidikan.html. ${ }^{9}$ Ibid.
} 
proses pengembangan. Kebanyakan orang mempertimbangkan implementasi adalah sebagai sesuatu yang tak dapat diramalkan dan tidak pasti.

Implementasi dapat dipandang sebagai rangkaian yang sangat teknis secara alami keseluruh aliran dan sangat estetis. Titik pusatnya adalah bahwa hal ini merupakan suatu komponen dala siklus tindakan kuriulum yang tidak bisa dilalikan. Langkah ini melibatkan tindakan luas yang tidak hanya sebagai contoh, perubahan tempat kerja untuk staff. Impelementasi merupakan usaha untuk mengubah pengetahuan, tindakan, dan sikap individu. Implementasi adalah suatu interaksi proses antara mereka yang menciptakan program dan mereka yang melaksanakannya. ${ }^{10}$

\section{Pengertian Kurikulum}

Kurikulum adalah suatu istilah dai bahasa asing yaitu Kurikulum (Curriculum) yang berasal dari kata curir (pelari) dan curere (tempat berpacu). Pada awalnya istilah ini digunakan dalam dunia olah raga. Pada saat itu kurikulum diartikan sebagai jarak yang harus ditempuh oleh seorang pelari mulai dari start sampai ke finish untuk memperoleh medali/penghargaan. Kemudian pengertian tersebut diterapkan dalam dunia pendidikan menjadi sejumlah mata pelajaran (subject) yang harus ditempuh oleh seorang siswa dari awal sampai akhir program pelajaran untuk memperoleh penghargaan dalam bentuk ijazah. ${ }^{11}$ Jadi istilah kurikulum sebagai kata benda dan digunakan dalam bidang olah raga, tetapi kemudian dirubah menjadi kata kerja dan digunakan dalam bidang pendidikan.

Dan dari pengertian kurikulum itu, Said Hamid Hasan (1988) mengemukakan bahwa, pada saat sekarang istilah kurikulum memiliki empat dimensi pengertian, dimana satu dimensi dengan dimensi lainnya saling berhubungan. Keempat dimensi kurikulum tersebut yaitu, Pertama, Kurikulum sebagai suatu ide atau gagasan; kedua, kurikulum sebagai suatu rencan tertulis yang sebenarnya merupakan perwujudan dari kurikulum sebagai suatu ide; ketiga, kurikulum sebagai suatu html.

${ }^{10} \mathrm{http}: / /$ www.agatossi.com/2012/09/evaluai-kualutas-kurikulum-pendidikan.

${ }^{11}$ Tim Pengembangan MKDP Kurikulum dan Pembelajaran (Bandung: PT Raja Grafindo Persada, 2011), hlm. 2. 
kegiatan yang sering pula disebut dengan istilah kurikulum sebaai suatu realita atau implementasi kurikulum secara teoritis, dimensi kurikulum ini adalah pelakanaan dari kurikulum sebagai suatu rencana tertulis; keempat. Kurikulum sebagai suatu asil yang merupakan konsekuensi dari kurikulum sebagai suatu kegiatan. ${ }^{12}$

Dikatakan juga bahwa pada dasarnya kurikulum berfungsi sebagai pedoman atau acuan. Bagi guru kurikulum berfungsi sebagai pedoman dalam melaksanakan proses pembelajaran. Bagi Kepala sekolah dan pengawas, kurikulum berfungsi sebagai pedoman untuk memberikan bantuan bagi terselengaranya proses pendidikan disekolah. Sedangkan bagi siswa, kurikulum berfungsi sebagai suatu pedoman belajar. ${ }^{13}$

Oemar Hamalik juga mengatakan bhwa pengertian kurikulum ialah jangka waktu yang ditempuh oleh siswa dalam menyelesaikan pelajarannya dengan tujuan untuk memperoleh ijazah. Dengan kata lain untuk memperoleh ijazah maka siswa harus menmpuh suatu kurikulum. Dan ijazah merupakan suatu bukti bahwa siswa telah menempuh kurikulum yang berupa rencana pelajaran dan telah menyelesaikannya sesuai dengan waktu yang ditentukan. Dimana kurikulum dianggap sebagai jembatan yag sangat penting untuk mencapai titik akhir dari suatu perjalanan dengan memperoleh ijazah. ${ }^{14}$

Ia juga mengatakan bahwa ada beberapa yang lain yaitu: Pertama, Kurikulum memuat isi dan materi pelajaran. Kurikulum ialah sejumlah mata pelajaran yang harus ditempuh dan dipelajari oleh siswa untuk memperoleh sejumlah pengetahuan. Kedua, Kurikulum sebagai rencana pembelajaran. Kurikulum adalah suatu program pendidikan yang disediakan untuk membelajarkan siswa. Melalui program itu para siswa melakukan berbagai kegiatan belajar, sehingga terjadi perubahan dan perkembangan tingkah laku siswa, sesuai dengan tujuan pendidikan dan pembelajaran. Ketiga, Kurikulum sebagai pengalaman belajar. Perumusan pengertian kurikulum lainnya yang agak berbeda dengan pengertian-pengertian sebelumnya lebih menekankan bahwa kuriklum merupakan serangkaian pengalaman belajar. ${ }^{15}$ Pengertian ini menunjukkan bahwa kegiatan-kegiatan kurikulum tidak terbatas hanya di kelas saja, tetapi mecakup semua kegiatan yang dilakukan diluar

${ }^{12}$ Tim Pengembangan MKDP Kurikulum dan Pembelajaran, hlm. 2.

${ }^{13}$ Ibid., hlm. 2-5.

${ }^{14}$ Oemar Hamalik, Kurikulum Dan Pembelajaran (Jakarta: Bumi Aksara, 2003), hlm. 16.

${ }^{15}$ Hamalik, Kurikulum Dan Pembelajaran, hlm. 16-17. 
kelas, jadi tidak ada pemisahan antara intra dan ekstra kurikulum bagi siswa semuanya itu adalah bagian dari kurikulum, sebab kurikulum adalah seperangkat rencana dan pengaturan mengenai isi dan bahan pelajaran serta cara yang digunakam sebagai pedoman penyelenggaraan kegiatan belajar mengajar. ${ }^{16}$ Jadi semua kegiatan belajar yang dilakukan oleh siswa dalam pendidikan baik itu kegiatan yang dilakukan dalam kelas maupun diluar kelas dan telah melibatkan siswa untuk memperoleh sejumlah pengetahuan dan pengalaman dan dapat menyelesaikan kegiatan belajarnya dengan tujuan untuk mendapat ijazah, maka itulah yang disebut Kurikulum.

\section{Fungsi Kurikulum Dalam Pendidikan}

Kurikulum sebagai alat pendidikan harus mampu menjawab berbagai tuntutan kemampuan penyesuaian diri yang diharapkan oleh seorang peserta didik, karena dengan adanya kurikulum anak akan memperoleh manfaat. Melalui kurikulum anak didik diharapkan mendapat sejumlah pengalaman baru yang kemudian hari dikembangkanna oleh anak agar dapat memenuhi bekal hidupnya nanti. Fungsi kurikulum tidak saja terbatas pada pemberian layanan bagi anak, tetapi juga memberi peluang bagi anak didik untuk memilih sesuai dirinya maupun tuntutan kebutuhan masyarakat. Dan pendidikan berfungsi untuk membantu mempersiapkan pesrta didik agar siap terjun ke masyarakat dan dapat mengembangkan diri secara maksimal potensi didalamnya. Pendidikan juga mempersiapkan peserta didik tidak saja untuk menghadapi tuntutan hari esok. Demikian juga untuk menyiapkan pesrta didik untuk menantang berbagai tuntutan baru karena ketidak puasan maupun karena adanya perkembangan individu secara berkelanjutan dari satu jenis dan tingkat perkembangan tertentu. Disinilah letak fungsi kurikulum sebagai alat pendidikan agar selalu dapat menyiapkan berbagai pengalaman-pengalaman yang bermakna bagi kelengkapan dan persiapan peserta didik untuk terjun dan hidup ditengah-tengah masyarakat. ${ }^{17}$

\footnotetext{
${ }^{16}$ Hamalik, Kurikulum Dan Pembelajaran, hlm. 18.

${ }^{17}$ H. Abdulah Idi, Pengemangan Kurikulum Teori Dan Praktek (Jogjakarta: ARRUZZ MEDIA, 2011), hlm. 228.
} 


\section{a. Fungsi Kurikulum Bagi Guru}

Guru sebagai fasilitator merupakan pelkasana atau implementator suatu kurikulum. Guru merupakan pendidik profesional yang telah merelakan dirinya untuk memikul sebagian tanggung jawab pendidikan yang ada di pundak orang tua. Karena orang tua telah menyerahkan anaknya ke sekolah, berarti orang tua sudah melimpahkan tanggung jawab pendidikan anaknya kepada guru, dengan harapan agar anaknya menemukan guru yang baik, kompeten dan berkualitas. Dan fungsi kurikulum bagi guru adalah sebagai pedoman kerja dalam menyusun dan mengorganisasi pengalaman belajar anak didik dalam rangka menyerap sejumlah pengalaman yang diberikan. ${ }^{18}$

Dengan adanya Kurikulum, maka tugas guru sebagai pendidik dan pengajar lebih terarah. Karena guru merupakan salah satu faktor yang sangat menentukan dan sangat penting dalam proses pendidikan, dan selalu berpean aktif dalam interksi dengan anak didik dalam pendidikan. Abdulah juga menjelaskan bahwa Langeveld mengajukan lima komponen yang berinteraksi secara aktif dalam proses pendidikan sebagai berikut: Pertama, Komposisi tujuan pendidikan, sebagai landasan idial pendidikan dan yang dicapai melalui proses pendidikan tersebut; Kedua, komponen terdidik, sebagai masukan manusiawi yang diperlukan sebagai subjek aktif dan dikenai proses pendidikan tersebut. Ketiga, Komponen alat pendidikan, sebagai unsur sarana atau objek yang dikenakan kepada terdidik dalam proses pendidikan. Keempat, Komponen pendidik, sebagai unsur manusiawi yang membantu mengenalkan alat pendidikan kepada anak didik dan mengarahkan proses pendidikan menuju sasaran yang diharapkan sebagaimana tercantum dalam tujuan pendidikan. Kelima, Komponen lingkungan pendidikan, sebagai unsur suasana yang membantu dan memberikan udara segar dalam proses pendidikan. ${ }^{19}$

\section{b. Fungsi Kurikulum Bagi Siswa}

Fungsi Kurikulum bagi siswa adalah sebagai berikut: Pertama, dengan wawasan semacam ini anak dapat mengetahui apa yang mereka lakukan dan apa yang mereka miliki untuk melihat hari esok. Kedua,

${ }^{18}$ Idi, Pengemangan Kurikulum Teori Dan Praktek, hlm. 229.

${ }^{19}$ Ibid., hlm. 230. 
Pada sisi lain siswa dapat mengukur potensi dirinya untuk mengadakan pilihan terhadap berbagai pengetahuan, pengalaman beajar serta aktivitas yang bersesuaian, jika ia ingin berhasil dalam proses pendidikan. Ketiga, Dengan kurikulum siswa dapat menyiapkan diri secara lebih baik dan optimal dalam proses pendidikan atau pembelajaran jika inginkan hasil yang baik. Keempat, Pada akhirnya sejalan dengan konsep atau pengertian modern tentang kurikulum dimana siswa dapat dilibatkan dalam pengembangan maka kurikulum dapat berfungsi bagi pengajuan usul perbaikan serta saran yang berguna dari kepentingan siswa. ${ }^{20}$

\section{c. Fungsi Kurikulum Bagi Kepala Sekolah/Pembina}

Kepala sekolah sebagai administrator dan supervisor, juga bertanggung jawab dalam melaksanakan kurikulum. Kepala sekolah memimpin, memonitor, mengontrol dan menilai setiap pelaksanaan kurikulum. Karena itu kurikulum memiliki fungsi tertentu bagi kepala sekolah atau pembina sekolah. Fungsi Kurikulum bagi kepala sekolah atau pembina adalah sebagai berikut: Pertama, sebagai pedoman dalam memimpin dan melaksanakan kurikulum. Kedua, sebagai pedoman dalam supervisi terutama dalam memperbaiki situasi belajar. Ketiga, Kurikulum sebagai pedoman dalam menyiapkan situasi belajar yang baik agar anak dapat belajar secara maksimal. Keempat, Sebagai pedoman dalam membantu guru dalam pelaksananaan kurikulum khususnya dalam proses belajar mengajar. Kelima, Kurikulum sebagai pedoman dalam melaksanakan administrasi dalam proses pembelajaran. Keenam, Sebagai pedoman dalam melaksanakan evaluasi kemajuan belajar maupun proes pembelajaran. Ketujuh, Kuriklum berfungsi dalam mengembangkan kurikulum lebih lanjut. ${ }^{21}$ Beberapa hal senada juga yang dikemukakan oleh $\mathrm{H}$. Abdullah mengenai fungsi kurikulum bagi kepala sekolah atau pembina adalah sebagai berikut: Pertama, sebagai pedoman dalam mengadakan fungsi supervisi, yaitu memeperbaiki situasi belajar. Kedua, sebagai pedoman dalam melaksanakan supervisi dalam menciptakan sitasi untuk menunjang siswa ke arah yang lebih baik. Ketiga, sebagai pedoman dalam

\footnotetext{
${ }^{20}$ Hari Santoso, Diktat kurikulum PAK I (Yogyakarta: Universitas Kristen Immanuel, 2001), hlm. 24.

${ }^{21}$ Santoso, Diktat kurikulum PAK I, hlm. 26.
} 
melaksanakan supervisi dalam memberikan bantuan kepada guru agar dapt memperbaiki situasi mengajar. Keempat, sebagai administrator yang menjadikan kurikulum sebagai pedoman untuk pengembangan kurikulum pada masa mendatang. Kelima, sebagai pedoman untuk mengadakan evaluasi atas kemajuan belajar mengajar. ${ }^{22}$

\section{d. Fungsi Kurikulum Bagi Orang Tua}

Fungsi kurikulum bagi orang tua menurt $\mathrm{H}$. Abdulah adalah bahwa Kurikulum difungsikan sebagai bentuk adanya partisipasi dari orang tua dalam membantu usaha sekolah untuk memajukkan puteraputerinya. Bantuan berupa konsultasi langsung dengan sekolah/guru mengenai masalah-masalah yang menyangkut anak-anak mereka. Bantuan dari orang tua anak berupa pemikiran atau materi dapat disalurkan melalui lembaga komite sekolah. Dengan membaca dan memahami kurikulum sekolah, para orang tua dapat mengetahui pengalaman belajar yang diperlukan anak-anak mereka, sehingga partisipasi orang tua inipun tidak kalah pentingnya dalam menyukseskan proses belajar mengajar di sekolah. ${ }^{23}$

Hal senada juga dikemukakan oleh Hari Santoso, yaitu bahwa kurikulum yang disiapkan untuk suatu lembaga pendidikan juga berfungsi bagi rang tua siswa. Fungsi kurikulum bagi orang tua adalah sebagai berikut: Pertama, orang tua dapat mengenal program sekolah secara utuh melalui pengetahuan, pengalaman-pengalaman belajar, berbagai kegiatan serta hal-hal yang telah diatur oleh sekolah bagi putera-puterinya. Kedua, melalui kurikulum tersebut orang tua dapat membantu sekolah dalam memajukan dan mendidik putera-puterinya demi masa depan putera-puterinya. Ketiga, Orang tua dapat berhubungan dan berkonsultasi dengan sekolah mengenai masalahmasalah yang berkaitan dengan pelaksanaan kurikulum. Keempat, orang tua juga dapat membantu secara langsung masalah yang dihadapi putera-puterinya dalam proses pembelajaran sesuai kemampuannya. ${ }^{24}$

\footnotetext{
${ }^{22}$ Idi, Pengembangan Kurikulum Teori Dan Praktik, hlm. 231.

${ }^{23}$ Ibid., hlm. 231-232.

${ }^{24}$ Santoso, Diktat Kurikulum PAK I, hlm. 27.
} 


\section{e. Fungsi Kurikulum Bagi Masyarakat}

Kurikulum adalah alat produsen dalam hal ini adalah sekolah, sedangkan masyarakat adalah konsumenna. Maka antara produsen dan konsumen harus sejalan. Keluaran atau output kurikulum sekolah harus dapat link and match dengan kebutuhan masyarakat. Berbagai jenis kurikulum sekolah dalam hubungannya dengan harapan masyarakat adalah sebagai berikut:

Pertama, pendidikan umum kurikulumnya mengutamakan perluasan pengetahuan dan peningkatan keterampilan dengan pengkhususan yang diwujudkan pada tingkat-tingkat akhir masa pendidikan.

Kedua, pendidikan kejuruan kurikulumnya mempersiapkan peserta para didik untuk dapat bekerja dalam bidang-bidang tertentu di masyarakat.

Ketiga, pendidikan keagamaan kurikulumnya menyiapkan penguasaan pengetahuan khusus pendidikan agama yang bersangkutan dengan harapan lulusannya dapat menjadi pembina agama yang baik di masyarakat.

Keempat, pendidikan akademik kurikulumnya menyiapkan penguasaan ilmu pengetahuan agar lulusannya dapat menjadi perintis atau pelopor pembangunan atas dasar konsep yang tangguh.

Kelima, pendidikan luar biasa kurikulumnya disediakan bagi peserta didik yang menyandang kelainan untuk disiapkan agar dapat menyesuaikan diri dalam kehidupan masyarakat.

Keenam, pendidikan kedinasan kurikulumnya disiapkan oleh suatu Departemen Pemerintah atau Lembaga Pemerinah Nondepartemen dengan maksud untuk meningkatkan kemampuan dalam pelaksanaan tugas kedinasan di masyarakat nantinya.

Ketujuh, pendidikan Profesional kurikulumnya menyiapkan penerapan keahlian tertentu dengan harapan lulusannya dapat bekerja secara profesional di masyarakat. ${ }^{25}$

${ }^{25}$ Lise Chamisijatin, dkk, Pengembangan Kurikulum SD, Direktorat jemderal Pendidikan Tinggi Departemen Pendidikan Nasional, 2008, hlm. 18-19. 


\section{Landasan Pengembangan Kurikulum}

Landasan pengembangan kurikulum memiliki peranan yang sangat penting, sehingga apabila kurikulum diibaratkan sebagai sebuah bangunan gedung ang tidak menggunakan landasan atau fondasi yang kuat, maka ketika diterpa angin atau goncangan, bangunan gedung tersebutakan mudah roboh. Demikian pula halnya dengan kurikulum, apabila tidak memiliki dasar pijakan yang kuat, maka kurikulum tersebut akan mudah termbang-ambing dan yang akan dipertaruhkan adalah manusia (peserta didik) yang dihasilkan oleh pendidikan itu sendiri.

Berdasarkan pendapat diatas maka ada empat landasan pokok dalam pengembangan kurikulum yaitu Landasan filosofi, landasan psikologis, landasan sosiologis, dan landasan ilmu pengetahuan dan teknologi (Iptek). ${ }^{26}$ Dari keempat hal inilah yang menjadi landasan pokok bagi pengembangan kurikulum Pendidikan di Indonesia yang menjadi landasan pokok yang dijadikan sebagai dasar dalam pengembangan kurikulum, yaitu:

Pertama, landasan filosofi yaitu asumsi-asumsi tentang hakekat realitas, hakekat manusia, hakekat pengetahuan, dan hakekat nilai yang menjadi titik tolak dalam mengembangkan kurikulum. Asumsi-asumsi filosofis tersebut berimplikasi pada perumusan tujuan pendidikan, pengembangan isi atau materi pendidikan, penentuan strategi, serta pada peranan yang sangat penting yaitu peranan peserta didik dan peranan pendidik.

Kedua, landasan psikologis, adalah asumsi-asumsi yang besumber dari psikologi yang dijadikan sebagai titik tolak dalam mengembangkan kurikulum. Ada dua jenis psikologis yang harus menjadi acuan, yaitu Psikologi perkembangan dan psikologi belajar. Psikologi perkembangan mempelajari proses dan karakteristik perkembangan peserta didik sebagai subjek pendidikan, sedangkan psikologi belajar mempelajari tingkah laku pesrta didik dalam situasi belajar. Ada tiga jenis teori belajar yang mempunyai pengaruh besar dalam pengembangan kurikulum, bagi peserta didik yaitu teri belajar kognitif, behavioristik, dan humanistik.

Kedua, landasan ilmiah dan teknologi, adalah asumsi-asumsi yang bersumber dari sosiologis dan antropologi yang dijadikan titik tolak

${ }^{26}$ Tim Pengebangan MKDP Kurikulum Dan Pembelajaran, hlm. 16. 
dalam mengembangkan kurikulum. Karakteristik sosial budaya dimana peserta didik hidup berimplikasi pada program pendidikan yang akan dikembangkan dalam proses belajar mengajar.

Ketiga, landasan ilmiah dan teknologi, adalah asumsi-asumsi yang bersumber dari hasil-hasil riset atau penelitian dan aplikasi dari ilmu pengetahuan yang ilmiah dan teknologi baik yang bersifat hardware maupun software sehingga pedidikan yang dilaksanakan dapat menyesuaikan diri dengan perkembangan ilmu engetahuan dan teknologi. ${ }^{27}$

\section{Kurikulum Dan Pembelajaran}

Dalam dunia pendidikan kurikulum mempunyai peran yang sangat penting bagi proses belajar dan pembelajaran. Dalam proses pendidikan selalu terjadi kegiatan belajar dan pembelajaran. Dan dari pembelajaran itu ada tujuan yang hendak dicapai yaitu kebutuhan siswa, mata pelajaran dan guru yang mengajar. Berdasarkan kebutuhan siswa dapat ditetapkan apa yang hendak dicapai dan dikembangkan. Lalu berdasarkan mata ajaran yang ada dalam petunjuk kurikulum dapat ditentukan hasil-hasil pendidikan yang diinginkan. Dan guru sendiri adalah sumber utama tujuan bagi para siswa dan dia harus mampu menulis dan memilih tujuan-tujuan pendidikan yang bermakna dan dapat terukur. Selain perkembangan anak banyak juga dipertimbangkan kebutuhan siswa sebagai sumber untuk menentukan apa yang akan diajarkan. $^{28}$

\section{UPAYA YANG DILAKUKAN}

\section{Cara Yang Dapat Dilakukan Untuk Meningkatkan Kualitas Implementasi Kurikulum}

Salah satu cara yang perlu dikembangkan untuk meningkatkan kualitas implementasi kurikulum adalah bahwa setiap lembaga pendidikan harus mengikuti proses pengembangan kurikulum karena

${ }^{27}$ Tim Pengembangan MKDP Kurikulum Dan Pembelajaran, hlm. 43-44.

${ }^{28}$ Hamalik, Kurikulum Dan Pembelajaran, hlm. 76. 
ada dua proses utama yaitu pengembangan pedoman kurikulum dan pengembangan pedoman instruksional.

1. Pedoman kurikulum meliputi:

a. Latar belakang yang berisi rumusan falsafah dan tujuan lembaga pendidikan, populasi yang menjadi sasaran, rasional bidang studi atau mata kuliah, struktur organisasi bahan pelajaran.

b. Silabus yang berisi mata pelajaran secara lebih terinci yang diberikan yakni ruang lingkup dan urutan penyajiannya.

c. Desain evaluasi termasuk strategi revisi atau perbaikan kurikulum mengenai: Bahan pelajaran, organisasi bahan dan strategi intruksionalnya.

2. Pedoman instruksional untuk tiap mata pelajaran yang dikembangkan berdasarkan silabus. ${ }^{29}$

\section{a. Pedoman Kurikulum}

Pedoman kurikulum disusun agar dapat digunakan untuk menentukan garis besarnya. Dan garis besarnya merupakan pokok penting yang harus diperhatikan dalam pedoman kurikulum yaitu, Pertama, Apa yang akan diajarkan, Kedua, Kepada siapa diajarkan, Ketiga, apa sebab diajarkan, dengantujuan apa. Keempat, dalam urutan yang bagaimana. ${ }^{30}$

Selanjutnya dari pedoman kurikulum tersebut dapat diuraikan sebagai berikut:

1. Falsafah lembaga pendidikan atau sekolah

2. Alasan atau rasional kurikulum berhubungan dengan opulasi yang jadikan sasaran, yakni untuk apa siswa dipersiapkan

3. Tujuan filosofis mengenai bahan yang akan diajarkan, alasan memilihnya.

4. Organisasi bahan pelajaran secara umum. ${ }^{31}$

${ }^{29}$ Nasution, Kurikulum Dan Pengajaran, hlm. 8.

${ }^{30}$ Ibid.

${ }^{31}$ Nasution, Kurikulum Dan Pengajaran, hlm. 9-10. 
Dalam pengembangan pedoman kurikulum, didalam garis besarnya ada langkah-langkah sebagai berikut: Pertama, Kumpulkan keterangan mengenai faktor-faktor yang turut menetukan kurikulum serta latar belakangnya. Kedua, tentukan mata pelajaran atau mata kuliah yang akan diajarkan. Ketiga, rumuskan tujuan tiap mata pelajaran. Keempat, tentukan hasil belajar yang diharapkan dari siswa dalam tiap mata pelajaran. Kelima, tentukan topik-topik tiap mata pelajaran. Keenam, tentukan syarat-syarat yang dituntut dari siswa. Ketujuh, tentukan bahan yang harus dibaca oleh siswa. Kedelapan, Tentukan strategi mengajar yang serasi serta sediakan berbagai sumber/alat peraga proses belajar mengajar. Kesembilan, tentukan alat evaluasi hasil belajar siswa serta skala penilaiannya. Kesepuluh, buat disain rencana penilaian kurikulum secara keseluruhan dari strategi perbaikannya. ${ }^{32}$

Berkaitan dengan mengembangkan pedoman kurikulum untuk meningkatkan kualitas kurikulum, maka menyusun silabus yang berisi pokok-pokok bahasan atau topik dan sub topik tiap mata pelajaran termasuk tanggung jawab guru atau pengajar di sekolah. Demikian juga dalam penyusunan pedoman instruksional, karena guru yang bertanggung jawab untuk merencanakan, menyusun, menyampaikan dan mengevaluasi satuan pelajaran. Karena itu guru atau dosen adalah pengembang kurikulum. ${ }^{33}$

\section{b. Pedoman Instruksional}

Pedoman Instruksional dapat diperoleh melalui usaha dari setiap guru untuk menguraikan isi pedoman kurikulum agar spesifik sehingga lebih mudah untuk mempersiapkannya sebagai materi pelajaran yang akan diajarkan dalam kelas, sehingga benar-benar bersumber dari pedoman kurikulum. Disamping itu untuk mempermudah pekerjaan dan lebih menjamin mutunya, maka penyusunan pedoman instruksional sebaiknya dilakukan oleh suatu tim, termasuk guru yang akan mengajarkannya. ${ }^{34}$

Untuk mendesain pedoman intruksional, maka dapat diperhatikan langkah-langkah sebagai berikut:

\footnotetext{
${ }^{32}$ Nasution, Kurikulum Dan Pengajaran, hlm. 9-10.

${ }^{33}$ Ibid., hlm. 11.

${ }^{34}$ Ibid.
} 
1. Tentukan satu atau dua Tujuan Instruksional umum (TIU) / Tujuan Pembelajaan umum (TPU) untuk tiap topik yang telah disebut dalam silabus.

2. Rumuskan Tujuan Instruksinal Khusus (TIK) / Tujuan Pembelajaran Khusus (TPK)

3. Tentukan dua atau tiga macam kegiatan belajar.

4. Sediakan sumber dan alat belajar mengajar yang sesuai

5. Buat Disain penilaian hasil dan kemajuan belajar, cara menilai, alat menilai untuk tiap tujuan khusus.

Dengan demikian maka dapat menolong guru untuk mempersiapkan materi pelajaran yang sesuai dengan pedoman kurikulum yang berlaku dan dapat meningkatkan kualitas kurikulum pendidikan. ${ }^{35}$

Untuk meningkatkan kualitas kurikulum, maka dalam pengembangan kurikulum harus relevan dengan perkembangan zaman. Karena apabila dikaitkan dengan pendidikan, berarti perlunya kesesuaian antara (program) pendidikan dengan tuntutan kehidupan masyarakat. Pendidikan dikatakan relevan bila hasil yang diperoleh akan berguna bagi kehidupan seseorang. Seperti yang dikutip dari soetopo dan soemanto (1993) dan subandijah (1993) mengungkapkan relevansi sebagai berikut: Pertama, Relevansi pendidikan dengan lingkungan anak didik. Relevansi ini memiliki arti bahwa dalam pengembangan kurikulum, termasuk alam menentukan bahan pengajaran, hendaknya disesuaikan dengan kehidupan nyata anak didik. Kedua, relevansi pendidikan dengan kehidupan yang akan datang. Materi atau bahan yang diajarkan kepada anak didik hendaklah memberi manfaat untuk persiapan masa depan anak didik. Karenanya keberadaan kurikulum disini bersifat antisipasi dan memiliki nilai prediksi secara tajam dan perhitungan. Ketiga, relevansi pendidikan dengan dunia kerja. Dimana anak dapat bekerja sesuai dengan disiplin ilmu yang didapat dan yang menjadi profesinya. Keempat, relevansi pendidikan dengan ilmu pengetahuan. Kemajuan pendidikan juga membuat maju ilmu pengetahuan dan teknologi. ${ }^{36}$

Oleh karena itu kurikulum dan proses pendidikan dapat diorientasikan ke unia kerja, menurut jenis pendidikan sehingga pengetahuan melalui teori di bangku sekolah dapat diaplikasikan

\footnotetext{
${ }^{35}$ Nasution, Kurikulum Dan Pengajaran, hlm. 13.

${ }^{36}$ Idi, Pengembangan Kurikulum, hlm. 201-202.
} 
dengan baik dalam dunia kerja nanti. Dan melalui pengembangan kurikulum dan proses pendidikan yang sesuai, maka dapat meningkatkan kualitas kurikulum.

\section{Pengertian Moralitas}

Istilah moralitas menurut Kamus Besar Bahasa Indonesia adalah sopan santun segala sesuatu yang berhubunngan dengan etiket atau adat sopan santun. Jadi moralitas adalah segala sesuatu yang berhubungan dengan sopan santun. ${ }^{37}$

Sam Silitonga, memberikan pendapatnya mengenai pengertian moralitas secara umum. Perkataan moralitas berasal dari kata Mos atau Mores (Bahasa Latin) yang sering diartikan sebagai, "Kelakuan Lahir seseorang," padahal kata moral dan etiket adalah dua kata yang sama artinya. Dan secara umum moralitas itu dikaitkan dengan norma dan kebiasaan hidup yang diakui secara umum. Adat istiadat, tradisi dan ajaran agama yang dominan dalam masyarakat, menjadi acuan utama untuk menilai seseorang apakah bermoral atau tidak. Dan jika seseorang tidak berprilaku baik sesuai adat dan kebiasaan hidup, maka orang ini akan dinilai kurang bermoral atau tidak bermoral. Jadi moralitas ditampakkan tidak hanya dalam perkataan, tetapi juga dalam sikap, perbuatan dan tindakan termasuk cara berpakaian dan berinteraksi dengan orang lain. ${ }^{38}$

Dikatakan juga bahwa ajaran agama sebagai sumber moramalias. Selain ajaran adat, kebiasaan hidup, dan falsafah hidup, satu lagi fakta yang mempengaruhi moralitas adalah ajaran agama. Ajaran agama menjadi sumber moral yang paling dominan dalam hidup manusia. Ajaran agama yang dianut dan diamalkan secara konsisten akan menimbulkan moralitas yang kuat. Ajaran agama yang dipahami dengan cara berpikir tertentu dan sikap mental yang terbentuk sedemikian rupa akan memunculkan moralitas umat beragama dengan corak tertentu. ${ }^{39}$

Frans Mgnis Suseno juga menjelaskan tentang sikap moral yang sebenarnya disebut moralitas. Moralitas adalah ikap hati orang yang

\footnotetext{
${ }^{37}$ Hasan, Kamus Besar Bahasa Indonesia, hlm. 665.

${ }^{38}$ Sam Silitonga, Bahan Ajar Agama Kristen di Perguruan Tinggi (Medan: Penerbit Mitra, 2011), hlm. 36.

${ }^{39}$ Ibid., hlm. 38-39.
} 
terungkap dalam tindakan lahiriah (mengingat bahwa tindakan merupakan ungkapan sepenuhnya dari sikap hati). Moralitas terdapat apabila orang mengambil sikap yang baik karena ia sadar akan kewajiban dan tanggung jawabnya dan bukan karena ia mencari untung. Moralitas adalah sikap perbuatan baik yang betul-betul tanpa pamrih. Hanya moralitaslah yang bernilai secara moral. ${ }^{40}$

Jadi yang dimaksudkan dengan sikap mral atau moralitas adalah sikap atau perbuatan baik dari seseorang yang sungguh-sungguh keluar dalam hati dengan kesadaran penuh dan betul-betul tanpa pamrih. Dan menurut Roert P. Borrong yang menjelaskan tentang moral menurut pandangan Kristen, yaitu, bahwa moral mengandung arti suatu tindakan yang dilandaskan atas norma kebenaran, kebaikan, dan kepatutan. Namun norma kebenaran, kebaikan, dan kepatutan itu tidak serta merta dapat diberlakukan dalam setiap situasi kehidupan yang dihadapi umat manusia. Selalu ada pertimbangan lain sebelum kita menyimpulkan bahwa suatu keputusan maupun tindakan kita dapat dibenarkan atau dianggap baik dan patut. Misalnya, situasi: antara situasi biasa dan situasi darurat tentu penerimaan suatu tindakan berbeda menurut situasi itu. Seorang yang membunuh dalam situasi damai dipastikan tidak bermoral. Artinya dia melakukan pembunuhan secara semena-mena. Tetapi seorang yang terpaksa membunuh dalam keadaan perang atau kacau, belum tentu membunuh karena tidak bermoral. Ia sangat sadar bahwa membunuh adalah perbuatan salah, buruk dan tidak patut; tetapi ia melakukannya untuk mencegah situasi yang lebih buruk, misalnya ia membunuh seorang yang mengancam keselamatan banyak orang. ${ }^{41}$

Jadi menurut pandangan Kristen, yaitu bahwa moral adalah suatu tindakan yang dilakukan berdasarkan kebenaran, kebaikan dan kepatutan bagi semua umat manusia di dalam lingkungan setiap hari.

\section{Cara Yang Dapat Dilakukan Bagi Pengembangan Moralitas}

Cara yang dapat dilakukan bagi pengembangan moralitas siswa di sekolah Kristen adalah menampakakn ciri khas pendidikan Kristen

\footnotetext{
${ }^{40}$ Frans Magnis Suseno, Etika Dasar Masalah-masalah Pokok Filsafat Moral (Yogyakarta: Kanisius, 1978), hlm. 58.

${ }^{41}$ Robert P. Borrong, Etika Seksual Kontemporer (Bandung: Ink Media, 2006), hlm. 115-116.
} 
dalam masyarakat majemuk memerlukan suatu kebijaksanaan khusus sesuai denan tantangan-tantangan yang berkembang di dalam masyarakat sekitar. Identitas dan ciri khas pendidikan Kristen terlihat dalam penampilan nilai-nilai kristiani, antara lain kasih, kebenaran, keadilan didalam seluruh situasi dan penyelenggaraan fungsi-fungsi sekolah. Setiap orang yang masuk dalam lingkungan sekolah Kristen menyaksikan suatu suasana yang diwarnai oleh nilai-nilai iman Kristen, seperti suasana damai, kegairahan bekerja, keakraban, atau saling menghargai. Suasana seperti ini dapat diciptakan melalui fungsi-fungsi sekolah:

a. Fungsi Pengajaran. Nilai-nilai kristiani ditampilkan dalam pengelolaan proses belajar mengajar dan pengelolaan kelas. Disini guru dan peserta didik adalah dua kelompok manusia yang mempunyai kedudukan yang setara dihadapan Tuhan dengan peranan yang berbeda. Guru sebagai pengelola kegiatan belajar mengajar perlu memasukan nilai-nilai afektf dalam pengajarannya sebagai tuntutan dari program pengajaran. Selain itu guru tidak hanya menyampaikan materi pengajaran didalam kelas sebagaimana terdapat dalam buku-buku teks, tetapi perlu menyampaikannya dengan wawasan keilmuan yang dimilikinya yang bersumber dari pernyataan Tuhan dalam firman-Nya.

b. Penilaian hasil belajar. Sering dalam kenyataannya guru mendongkrak nilai hasil belajar siswa yang didasarkan pada rasa kasian. Akan tetapi hal ini tidak lagi menyatakan kebenaran dan kedilan, karena apa yang diperoleh siswa tidak sesuai dengan prestasi yang ditunjukkannya. Akibat dari kebijaksanaan ini akan merugikan perkembangan pribadi peserta didik di kemudian hari. Penilaian hasil belajar merupakan pertanggung jawaban pekerjaan pendidikan terhadap lembaga pendidikan, pemakai lulusan, orang tua peserta didik, dan yang paling penting ialah kepada ialah kepada Tuhan sendiri.

c. Fungsi bimbingan dan konseling. Penampilan nilai-nilai kristiani sangat efektif dalam fungsi ini. Fungsi ini bukan hanya tanggung jawab guru bimbingan, melainkan setiap guru khususnya guru tetap. Ibadah buka dan tutup minggu serta doa pagi dan doa menutup pelajaran setiap hari dan kegiatankegiatan ritual keagamaan selama ini telah berjalan hampir di seluruh sekolah Kristen. Pelaksanaannya perlu ditingkatkan supaya tidak dilaksanakan sebagai tradisi, melainkan sebagai 
ungkapan dari penghayatan iman dan pergumulan sehari-hari dalm melaksanakan misis sekolah Kristen. ${ }^{42}$

Andar Ismail juga mengatakan bahwa ada beberapa manfaat dan sumbangan dari ilmu-ilmu sosial yaitu:

1. Pertama-tama gereja diingatkan agar bersikap hati-hati dalam pendidikannya dalam hal menilai murid-murid, mengadili dan menghukum mereka.

2. Adat kebiasaan, keadaan ekonomi, peranggapan-peranggapan, prasangka-prasangka, falsafah hidup orang dan bangsa, iptek maju, kesemuanya turut mempengaruhi nilai-nilai moral orang. Inilah faktor-faktor yang perlu dipertimbangkan dalam penilaian moral di sekolah dan gereja.

3. Lingkungan sosial, perkembangan kognitif orang, dan empati terhadap murid dapat menjadi faktor-faktor berpengaruh meskipun sifatnya tak menentukan terhadap nilai-nilai moral yang dipegang setiap orang. Implikasinya bagi pendidikan adalah agar guru mengusahakan kelasnya menjadi tempat yang suasananya menyenangkan, terbuka untuk berdiskusi tentang pokok pelajaran berbagi rasa antara guru, murid dan sesama murid.

4. Pentinglah artinya untuk merangsang murid-murid dengan mengkonfrontasikan mereka dengan masalah-masalah dari satu tahap di atas tahap-tahap mereka berada demi peningkatan tahap.

5. Usia bukanlah faktor menentukan dalam perkembangan moral, tetapi berpengaruh terhadap perkembangan moral. Itulah sebabnya metode dan teknik mengajar yang efektif perlu diusahakan dalam pengajaran. Teknik diskusi, bermain peran, drama (film) dan simulasi terbukti baik efeknya. Diskusi orang tua-anak dan guru-murid tentang masalah keadilan dan kebenaran banyak menolong anak-anak dan murid-murid. Memerankan tokoh-tokoh dalam cerita dalam dramatisasi, cerita-cerita Alkitab, atau menonton drama atau cerita baik dampaknya dalam pendidikan.

6. Perkembangan moral bukanlah hal yang terjadi secara otomatis, melainkan prosesnya berlangsung lambat laun. Implikasinya adalah bahwa guru-guru tak boleh mengharapkan hasil usaha pendidikan terjadi secara cepat atau kilat. Pendidik Kristen harus

${ }^{42}$ Weinata Sairin, Identitas Dan Ciri Khas Pedidikan Kristen di Indonesia (Jakarta: BPK Gunung Mulia, 2000), hlm. 104-105. 
mengajar dengan penuh kesabaran dan ketekunan, dan doa agar Roh Allah sendiri yang memberi hasil usahanya, karena ia menyadari hanya Tuhan sajalah yang dapat memberi buahnya.

7. Pengajaran hukuman dan hadiah-hadiah tak akan mengubah struktur dasar pemikiran orang. Hal yang lebih penting adalah memberi pengertian yang benar tentang pengajaran, hukuman yang diberi, dan mengapa hadiah-hadiah diberikan; ini dapat dilakukan dengan teknik diskusi, atau berbagi rasa.

8. Guru dan orang tua sebaiknya jangan mempraktekkan metode atau teknik secara otoriter. Gaya demikian bukan saja tak efektif, melainkan juga tidak kristiani.

9. Merencanakan program pendidikan sebaiknya disesuaikan dengan tahap-tahap dimana mereka, atau boleh satu tahap diatasnya, untuk mendapatkan hasil yang efektif dan optimal. Disini ternyata menimbulkan problem bagi pendidikan gereja, yang lazimnya mengikuti cara pembagian kelas dan pemakaian kurikulum pendidikan disekolah-sekolah biasa.

10. Tujuan pendidikan moral adalah perkembangan moral seoptimal mungkin. Tujuan demikian bukanlah upaya pendidikan yang mudah dicapai. Lebih-lebih lagi pelayanan pedagogis gereja pada akhir-akhirnya tergantung pada pekerjaan Allah sendiri-bukan terus usaha manusiawi. ${ }^{43}$

Beberapa manfaat diaas dapat digunakan untuk mengembangkan moralitas peserta didik, karena melalui proses belajar mengajar yang dilakukan oleh guru dapat menolong anak untuk merubah kelakuannya, sehingga lebih baik lagi. Upaya yang penting untuk dilakukan di sekolah oleh guru kepada siswa adalah dengan cara meningkatkan kualitas implementasi Kurikulum PAK melalui pembelajaran didalam kelas. Guru sebagai pengajar dan pendidik perlu membangun iman percaya dari setiap peserta didik dan guru harus menjadi contoh dan teladan yang baik bagi siswa sehingga siswa dapat mengikuti teladan yang baik itu. Disamping guru membimbing siswa, guru juga perlu memotivasi dan mendorong siswa untuk ikut terlibat dalam pelayanan gerejawi.

Karena identitas dan penyelenggaraan sekolah Kristen terletak pada motif dasar penyelenggaraan pendidikan itu sendiri. Pendidikan secara operasional sangat tergantung pada penghayatan iman Kristen

${ }^{43}$ Ismail, Ajarlah Mereka Melakukan, hlm. 76-77. 
bagi penyelenggaraannya. Dan untuk meningkatkan kualitas kurikulum itu guru juga dapat menilai kegiatan dan kemajuan belajar siswa untuk mengumpulkan informasi tentang kemajuan belajar mereka. Penilaian ini terutama berfungsi untuk meningkatkan mutu atau kualitas dari kegiatan serta tingkat kemajuan siswa dalam kurun waktu tertentu, misalnya: harian, mingguan, dan bulanan. Hasil penilaian ini dapat menjadi umpan balik bagi perencanaan, penyempurnaan, dan pelaksanaan kegiatan belajar mengajar. Di samping itu hasil penilaian ini dapat ula menjadi bahan pertimbangan bagi upaya perbaikan serta penyempurnaan hasil belajar siswa. ${ }^{44}$ Jadi dalam proses belajar mengajar banyak hal yang akan siswa dapati dalam belajar, baik melalui kegiatan belajar di kelas maupun dalam lingkungan hidup di keluarga setiap hari.

\section{PENUTUP}

Untuk mengakhiri penulisan jurnal ini, penulis merasa bahwa ini hal yang sangat penting untuk tetap diperhatikan oleh pemerintah, bangsa dan negara serta tetap diatur dalam peraturan pemerintah tentang Kurikulum Pendidikan Nasional, untuk meningkatkan mutu pendidikan bangsa, pada masa kini dan masa yang akan datang, agar pendidikan di Indonesia pada umumnya dan di Papua pada khususnya tidak ketinggalan tetapi mutunya semakin meningkat dalam memasuki era globalisasi dan pasar bebas sehingga kita bangsa Indonesa juga bisa bersaing dengan bangsa-bangsa lain di dunia.

Itu sebabnya perlu ada peningkatan kualitas implementasi kurikulum PAK sebagai upaya pengembangan moralitas bagi setiap pelajar yang sedang duduk dalam bangku pendidikan pada masa ini dan masa yang akan datang, sehingga betul-betul dapat terlihat adanya peningkatan kualitas implementasi kurikulum PAK dan juga ada upaya pengembangan moralitas pelajar juga dapat terlihat ke arah yang lebih baik.

Peran guru PAK di sekolah dan gereja sangat dibutuhkan bagi Peningkatan kualitas implementasi Kurikulum PAK dan juga sebagai

${ }^{44}$ Sairin, Identitas Dan Ciri Khas Pendidikan Kristen, hlm. 77. 
upaya dalam pengembangan moralitas bag para pelajar di sekolahsekolah, baik sekolah negeri maupun sekolah Kristen, sehingga dapat menbantu untuk mengembangkan moralitas bangsa dan negara.

\section{DAFTAR PUSTAKA}

Borrong, Robert P. Etika Seksual Kontemporer. Bandung: Ink Media, 2006.

Chamisijatin, Lise dkk. Pengembangan Kurikulum SD, Direktorat jemderal Pendidikan Tinggi Departemen Pendidikan Nasional, 2008.

Hamalik, Oemar. Kurikulum Dan Pembelajaran. Jakarta: Bumi Aksara, 2003.

Hasugian, Johanes Waldes. Menjadi Guru PAK Profesional Melalui Supervisi Pendidikan Agama Kristen. 2nd ed. Medan: CV. Mitra, 2016.

Hasugian, Johanes Waldes. Strategi Belajar Mengajar Pendidikan Agama Kristen Yang Efektif. Prodi Teologi STT-SU, 2016.

Hendra, Vitaurus. "Peran Orang Tua Dalam Menerapkan Kasih Dan Disiplin Kepada Anak Usia 2-6 Tahun Sebagai Upaya Pembentukkan Karakter." KURIOS (Jurnal Teologi dan Pendidikan Agama Kristen) 3, no. 1 (2015): 48-65. www.sttpb.ac.id/e-journal/index.php/kurios.

http://www.agatossi.com/2012/09/evaluai-kualutas-kurikulumpendidikan.html.

Idi, H. Abdulah. Pengemangan Kurikulum Teori Dan Praktek. Jogjakarta: AR-RUZZ MEDIA, 2011.

Kohlberg, Lawrence. Tahap-tahap Perkembangan Moral. Yogyakarta: Penerbit Kanisius, 1995.

Mulyasa, E. Kurikulum Berbasis Kompetensi. Bandung: PT Remaja Rosdakarya, 2004.

Santoso, Hari. Diktat kurikulum PAK I. Yogyakarta: Universitas Kristen Immanuel, 2001. 
Sairin, Weinata. Identitas Dan Ciri Khas Pedidikan Kristen di Indonesia. Jakarta: BPK Gunung Mulia, 2000.

Siahaan, Harls Evan Rianto. "Hikmat Sebagai Implikasi Pendidikan Kristiani Dalam Keluarga: Refleksi 1 Raja-Raja 3:1-15." DUNAMIS (Jurnal Teologi dan Pendidikan Kristiani) Vol 1, no. 1 (2016): 15-30. www.sttintheos.ac.id/ejournal/index.php/dunamis.

Silitonga, Sam. Bahan Ajar Agama Kristen di Perguruan Tinggi. Medan: Penerbit Mitra, 2011.

Sudjatmiko dan Lili Nurlaili. Kurikulum Berbasis Kompetensi dalam menunjang kecakapan hidup siswa, Departemen Pendidikan Nasional Direktorat Jenderal Pendidikan Dasar dan Menengah Direktorat Tenaga Kependidikan, 2004.

Suseno, Frans Magnis. Etika Dasar Masalah-masalah Pokok Filsafat Moral. Yogyakarta: Kanisius, 1978.

Tim Pengembangan MKDP Kurikulum dan Pembelajaran. Bandung: PT Raja Grafindo Persada, 2011.

Tim Penyusun. Kamus Besar Bahasa Indonesia, Edisi keempat. Jakarta: PT Gramedia Pustaka Utamaa, 2011. 